\title{
Quantitative morphometry of squamous cell hyperplasia of the larynx
}

\author{
P OLDE KALTER, ${ }^{*}$ H LUBSEN,${ }^{*} \S$ JFM DELEMARRE, $\dagger$ CL ALONS, $\ddagger$ \\ RW VELDHUIZEN, $₫$ CJLM MEYER, $\ddagger$ GB SNOW*
}

From the *Department of Otolaryngology and Head and Neck Surgery, $¥$ Pathological Institute, Free
University Hospital, and †Department of Pathology, Antoni van Leeuwenhoekhuis (The Netherlands Cancer
Institute), Amsterdam, The Netherlands

SUMMARY The histopathological diagnosis of squamous cell hyperplasia of the larynx is very subjective. Since morphometry is highly reproducible, this method was applied to routine processed slides of 45 such lesions to assess objectively the epithelial characteristics. In each case measurements of nuclei of 50 cells in the basal, intermediate, and superficial cell layers were carried out. The data were analysed statistically. The findings suggest that quantitative morphometry may be helpful for the histopathological classification of squamous cell hyperplasia of the laryngeal mucosa.

Considerable uncertainty and controversy still surround the so called precancerous lesions of the laryngeal mucosa. These lesions develop from squamous epithelium, and the changes in this epithelium include hyperplasia, keratosis, and atypia. Proper diagnosis is considerably hindered by the lack of an internationally accepted histopathological classification.

In North America the classification proposed at the Centennial Conference on Laryngeal Cancer ${ }^{1}$ is usually used: keratosis, keratosis with atypia, carcinoma in situ. Others have also based their classifications on the degree of dysplasia, ${ }^{2-6}$ giving three groups: group $1=$ hyperplasia or keratosis or both, with or without mild dysplasia; group $2=$ moderate dysplasia; and group $3=$ severe dysplasia and carcinoma in situ. In Europe a classification introduced by Kleinsasser is often used..$^{8}$ This classification consists of three classes: class $I=$ simple squamous cell hyperplasia; class II = squamous cell hyperplasia with atypia; class III = carcinoma in situ. Although the aforementioned classifications use a different nomenclature, they all distinguish three categories and, in fact, these categories more or less coincide. In the Netherlands Kleinsasser's

Present addresses: §Department of Otolaryngology, State University Utrecht; „Department of Automation and Information Processing, Free University Hospital; IDepartment of Pathology, Westeinde Ziekenhuis, Den Haag.

Accepted for publication 8 January 1985 classification has traditionally been used.

Kleinsasser,,$^{78}$ Delemarre, ${ }^{9}$ and Lubsen ${ }^{10}$ have all shown by means of retrospective clinical pathological analyses that Kleinsasser's classification has prognostic significance: the risk of future development of carcinoma increases from class I to class III. We therefore base our management policy on this classification. In all cases microsurgical removal of the entire lesion is attempted. When classes I or II are reported by the pathologist no further treatment is given and the patient is merely followed up. With class III lesions, depending on the age of the patient and the site and extent of the lesion, further treatment, consisting of either $\mathrm{CO}_{2}$ laser surgery or radiotherapy, is carried out.

Kleinsasser's classification, however, is subjective. In practice the problems encountered in the use of this classification focus particularly on the differential diagnosis between class II and III. Even between experienced pathologists in this field there is disagreement in diagnosis of a substantial number of cases. Furthermore, on review of the section, the classification is not always reproducible. It is therefore important to search for objective parameters which distinguish the different classes to improve the reproducibility of the grading of the hyperplastic laryngeal lesions so that optimal treatment of these lesions may be given. This study attempts to determine whether quantitative morphological analysis of the epithelial characteristics can contribute to the histopathological classification of squamous cell hyperplasia of the larynx. 

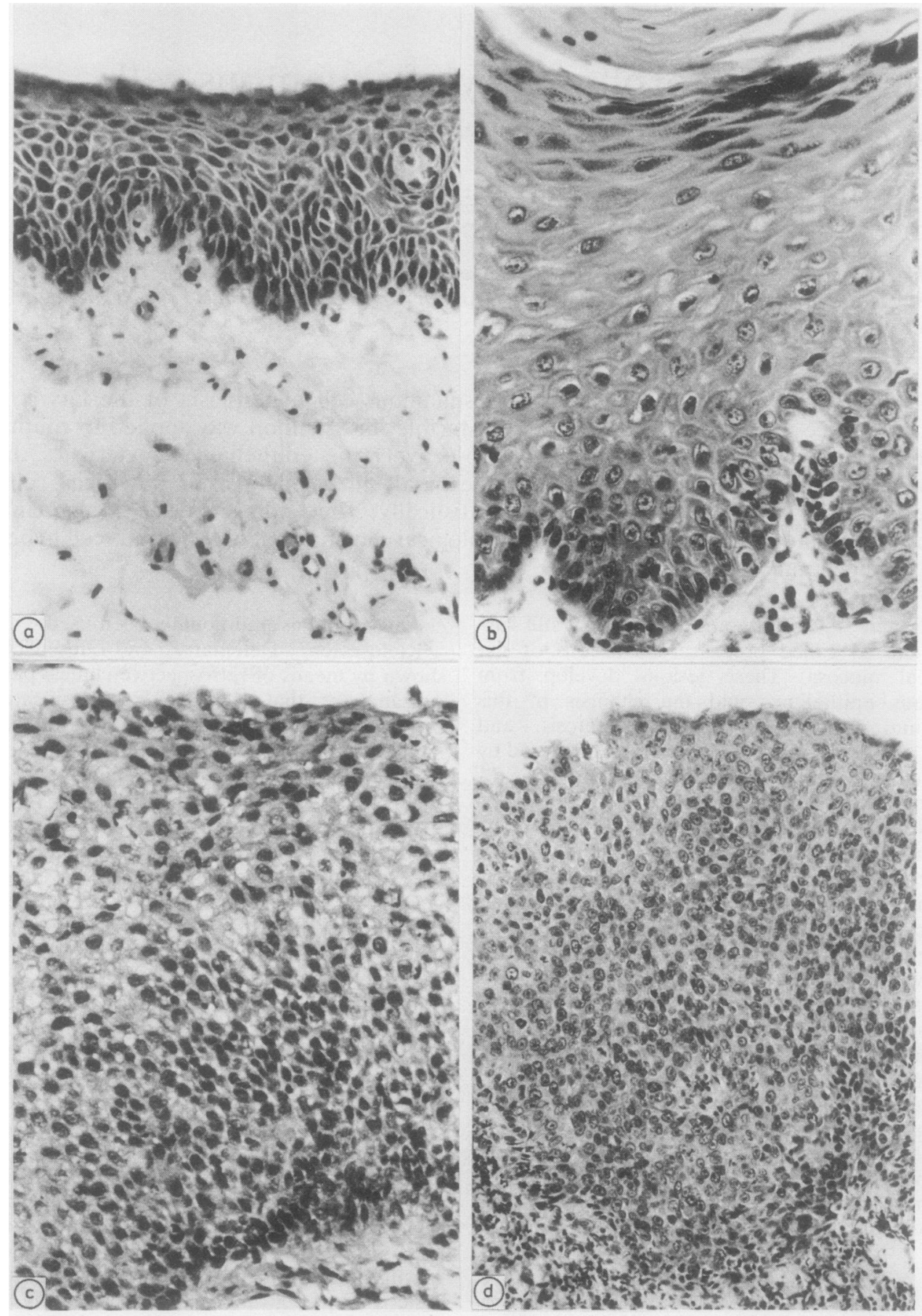

Fig. 1 (a) Normal squamous cell epithelium $(\times 330)$. (b) Simple squamous cell hyperplasia $(\times 330)$. (c) Squamous cell hyperplasia with atypia $(\times 330)$. (d) Carcinoma in situ $(\times 208)$. 
Material and methods

\section{MATERIAL}

A total of 50 microscope slides were examined. Forty five slides ( 15 each of class I, class II, and class III) were selected by two experienced, independent pathologists from a total of 275 slides pertaining to the patient material (total number of patients 187) of the Department of Otolaryngology, Free University Hospital, and the Netherlands Cancer Institute analysed earlier by Lubsen. ${ }^{10}$ These 45 slides were chosen at random, without knowledge of the patients' histories. Five slides from normal laryngeal epithelium were also included. All patients had been followed for at least six years.

\section{HISTOLOGY}

All laryngeal specimens were fixed in formalin and embedded in paraplast ( $4 \mu \mathrm{m}$ thick). The sections were stained with haematoxylin and eosin. Measurements for this study were carried out in three layers of the epithelium: the basal cell layer, consisting of one layer of basal cells; the prickle cell or intermediate cell layer; and the superficial cell layer. These layers are defined as follows: the basal cell layer is represented by a row of cells following the basal cell lamina; the superficial cell layer (or granular cell layer) is restricted to a superficial layer of three to five cells (below the stratum corneum when present) and characterised by densely distributed keratohyalin granules. In between these two strata is the remaining intermediate layer or stratum spinosum. ${ }^{11}$ Measurements in this layer are made in the middle of the epithelial width (measured from the basement membrane to the upper layer of the stratum granulosum).

\section{DEFINITION OF THE HISTOLOGICAL CLASSES}

According to Kleinsasser's classification, ${ }^{78}$ with modifications of Delemarre, ${ }^{9}$ in class I, simple squamous cell hyperplasia, there is a thickening of the epithelium and often a form of keratosis (Fig. 1b; Fig. 1a shows normal epithelium). There is, however, no atypia. Mitoses are rare and found only in the basal cell layer. Class II, squamous cell hyperplasia with atypia (Fig. 1c) shows all the characteristics of the former and, in addition, atypia. A moderate number of mitoses are seen, some of which might be atypical. The atypia does not involve the full height of the epithelium. Class III, carcinoma in situ (Fig. 1d), manifests the generally accepted characteristics of carcinoma with the exception of invasive growth. There is a full thickness epithelial replacement by atypical cells. Mitoses are frequent and not limited to the basal cell layer.
MORPHOMETRY AND STATISTICAL ANALYSIS

From each slide the most characteristic part of the lesion was selected for measurement by two experienced pathologists. Because the pathologist included the three layers of the epithelium in his evaluation of the lesion, 50 nuclei per cell layer were measured at random. The nuclear area, the nuclear contour index, and the polarity of these 50 cells were measured with a projection microscope $(100 \times)$. The slides were projected on to a graphic digitising tablet (Bit Pad One, Summagraphics Corporation) (Fig. 2). Additional measurements were made of the nuclear crowding and the epithelial width. With these parameters the characteristics of the classification (hyperplasia and atypia) were assessed. There were no differences of any significance between measurements done twice by the same person at different places within the areas selected by the pathologists (Table 1). The data were transferred to a computer (Cyber 750, Control Data). The mean values, standard deviations, and correlations were calculated (Statistical Package for Social Sciences). For statistical analysis, Wilcoxon's non-parametric two sample test was used. We also attempted to measure the cell size but the quality of these sections fixed in formalin did not allow for accurate measurement of the cell size.

The following morphometric parameters, all carried out in the three cell layers, with exception of no 5 and no 6, were used to compare the three classes of Kleinsasser's classification:

1 The mean nuclear area (in $\mu \mathrm{m}^{2}$ ).

2 The mean nuclear contour index (NCI), as given by the formula

$$
\mathrm{NCI}=\frac{\mathrm{P}}{\sqrt{\mathrm{A}}},
$$

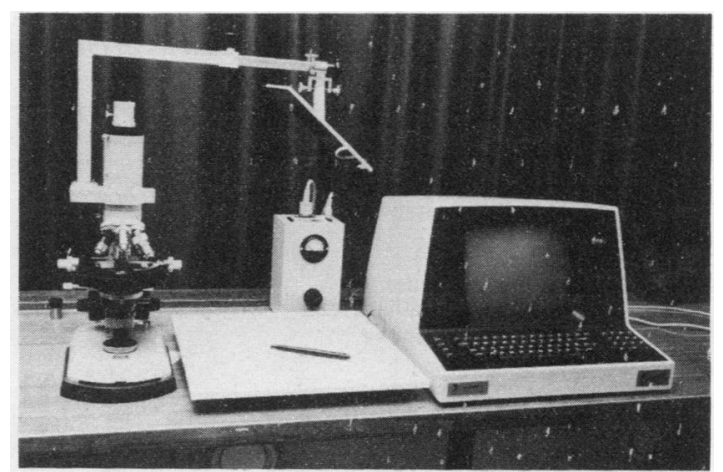

Fig. 2 Technical equipment. At the centre the digitising tablet on which the microscope image is projected by a mirror. On the right the standard computer terminal on which the results are shown. The average time to measure 50 cells is 15 min. 
Table 1 Examples of the mean nuclear areas, the mean nuclear contour indices, and the mean nuclear polarities of 50 cells of the intermediate layer of three cases (1 class I, 1 class II, and 1 class III), measured twice at different places within the same area by the same person

\begin{tabular}{|c|c|c|c|c|}
\hline & Measurement & Class 1 & Class 2 & Class 3 \\
\hline $\begin{array}{l}\text { Mean nuclear area }\left(\mu \mathrm{m}^{2}\right) \\
\text { intermediate layer } \\
\text { Mean nuclear contour index } \\
\text { intermediate layer } \\
\text { Mean nuclear polarity (radians) } \\
\text { intermediate layer }\end{array}$ & $\begin{array}{l}1 \\
2 \\
1 \\
2 \\
1 \\
2\end{array}$ & $\begin{array}{l}71 \cdot 04 \\
72.28 \\
3.64 \\
3.69 \\
0.74 \\
0.70\end{array}$ & $\begin{array}{r}103 \cdot 23 \\
101.98 \\
3.61 \\
3.63 \\
1.31 \\
1.35\end{array}$ & $\begin{array}{r}90 \cdot 90 \\
92 \cdot 11 \\
3 \cdot 69 \\
3 \cdot 72 \\
1 \cdot 71 \\
1 \cdot 76\end{array}$ \\
\hline
\end{tabular}

where $\mathbf{P}$ denotes the perimeter of the nucleus and $\mathrm{A}$ the nuclear area. The NCI is a size independent shape parameter. Its minimal value is found for a circle and is 3.545

$$
\left(\frac{2 \pi \mathrm{R}}{\sqrt{\pi \mathrm{R}^{2}}}=2 \sqrt{\pi}=3 \cdot 545\right) \text {. }
$$

It increases when the nuclear irregularity increases. ${ }^{12}$

3 The mean polarity of the nuclei, a parameter for nuclear axis orientation. The angle between the long axis of the nuclei and the local basement membrane was used as a measure of the polarity of the nuclei. The direction of the long axis was estimated by the computer from the coordinates of the perimeter points, obtained during the measurement of the nuclear area. This results in a mean nuclear polarity of nuclei in the basal cell layer (when the axes are generally orientated perpendicular to the local basement membrane) of \pm 1.57 radians $\left(360^{\circ}=2 \pi\right.$ radians $=6.2830$ radians; 1 radian $\approx 60^{\circ}$ ) and in a mean nuclear polarity of the nuclei in the superficial layer (when the axes are generally orientated parallel to the surface) of \pm 0.0 radians.

4 The total number of nuclei per (arbitrary) square unit. The number of nuclei per square unit in the specimen is a measure of nuclear crowding (number of nuclei per unit volume). ${ }^{13}$

5 The maximum width of the epithelium, a measure of hyperplasia (arbitrary units). Strictly speaking, only a plane that is cut perpendicular to the epithelial surface (and if possible also perpendicular to the basement membrane) can serve for a proper measurement of the epithelial thickness. Only those parts of the sections which were vertical to the epithelial surface were selected for the measurement. No matter what method is applied this parameter remains somewhat unreliable.

6 The maximum width of the stratum corneum, a measure for (hyper) keratosis.

7 The standard deviation (SD) for the various mean nuclear areas, mean nuclear contour indices, and mean nuclear polarities: SD nuclear area may be considered a measure of anisokaryose; SD nuclear contour index a measure of polymorphia; and SD nuclear polarity a measure of irregularity or architectural disturbance of the corresponding epithelial layer.

\section{Results}

Table 2 gives the results of the measurements of the

Table 2 Mean values and standard deviations of the measurements of normal squamous cell epithelium and of the three classes of squamous cell hyperplasia

\begin{tabular}{|c|c|c|c|c|}
\hline & Normal & Class I & Class II & Class III \\
\hline $\begin{array}{l}\text { Mean epithelial width (au) } \\
\text { Mean width stratum corneum (au) } \\
\text { Basal cell layer }\end{array}$ & $\underline{-}^{0.23 \pm 0.11}$ & $\begin{array}{l}0.51 \pm 0.26 \\
0.17 \pm 0.32\end{array}$ & $\begin{array}{l}0.58 \pm 0.29 \\
0.16 \pm 0.22\end{array}$ & $\begin{array}{l}0.43 \pm 0.23 \\
0.07 \pm 0.06\end{array}$ \\
\hline $\begin{array}{l}\text { Mean nuclear area }\left(\mu \mathrm{m}^{2}\right) \\
\text { Mean nuclear contour index } \\
\text { Mean nuclear polarity (radians) } \\
\text { Mean nuclear crowding (au) }\end{array}$ & $\begin{array}{c}56.28 \pm 5.9 \\
3.81 \pm 0.23 \\
1.27 \pm 0.13 \\
50.4 \pm 6.2\end{array}$ & $\begin{array}{r}52.72 \pm 13.7 \\
3.73 \pm 0.18 \\
1.33 \pm 0.12 \\
46.4 \pm 13.7\end{array}$ & $\begin{array}{r}76.98 \pm 28.6 \\
3.82 \pm 0.14 \\
1.46 \pm 0.16 \\
32.1 \pm 10.4\end{array}$ & $\begin{array}{r}72.62 \pm 26.8 \\
3.82 \pm 0.12 \\
1.67 \pm 0.18 \\
38.8 \pm 12.1\end{array}$ \\
\hline $\begin{array}{l}\text { Intermediate cell layer } \\
\text { Mean nuclear area }\left(\mu \mathrm{m}^{2}\right) \\
\text { Mean nuclear contour index } \\
\text { Mean nuclear polarity (radians) } \\
\text { Mean nuclear crowding (au) }\end{array}$ & $\begin{array}{c}91.01 \pm 14.8 \\
3.69 \pm 0.05 \\
0.38 \pm 0.22 \\
34.4 \pm 2.6\end{array}$ & $\begin{array}{r}72.23 \pm 15.1 \\
3.64 \pm 0.09 \\
0.73 \pm 0.31 \\
25.6 \pm 5.0\end{array}$ & $\begin{array}{r}108.29 \pm 33.1 \\
3.66 \pm 0.07 \\
1.21 \pm 0.52 \\
24.8 \pm 8.8\end{array}$ & $\begin{array}{c}95.68 \pm 22.9 \\
3.7 \pm 0.1 \\
1.78 \pm 0.33 \\
30.2 \pm 10.3\end{array}$ \\
\hline $\begin{array}{l}\text { Superficial cell layer } \\
\text { Mean nuclear area }\left(\mu \mathrm{m}^{2}\right) \\
\text { Mean nuclear contour index } \\
\text { Mean nuclear polarity (radians) } \\
\text { Mean nuclear crowding (au) }\end{array}$ & $\begin{array}{c}55.2 \pm 14.6 \\
4.18 \pm 0.23 \\
0.21 \pm 0.1 \\
21.6 \pm 4.7\end{array}$ & $\begin{array}{c}59.9 \pm 13.1 \\
3.80 \pm 0.11 \\
0.27 \pm 0.12 \\
17.2 \pm 5.3\end{array}$ & $\begin{array}{c}83.9 \pm 39.5 \\
3.84 \pm 0.17 \\
1.13 \pm 0.74 \\
15.0 \pm 4.8\end{array}$ & $\begin{array}{c}66.0 \pm 14.2 \\
3.87 \pm 0.13 \\
1.64 \pm 0.68 \\
25.3 \pm 8.7\end{array}$ \\
\hline
\end{tabular}

au $=$ arbituary units. 
Table 3 Significance of differences* between classes I, II, III, and normal epithelium

\begin{tabular}{|c|c|c|c|c|}
\hline & Class I-Normal & Classes I-II & Classes I-III & Classes II-III \\
\hline Mean epithelial width & $\mathrm{p}<0.05$ & - & - & $p=0.07$ \\
\hline $\begin{array}{l}\text { Mean width stratum corneum } \\
\text { Basal cell layer }\end{array}$ & $\mathrm{p}<0.05$ & - & - & \\
\hline Mean nuclear area & - & $\mathrm{p}<0.01$ & $\mathrm{p}<0.05$ & - \\
\hline Mean nuclear contour index & - & - & $\underline{-}-000$ & - \\
\hline Mean nuclear polarity & - & $\mathrm{p}<0.05$ & $\mathrm{p}<0.01$ & $\mathrm{p}<0.01$ \\
\hline SD nuclear area & - & $\mathrm{p}<0.01$ & $\mathrm{p}<0.01$ & - \\
\hline SD nuclear contour index & - & 一 & - & - \\
\hline $\begin{array}{l}\text { SD nuclear polarity } \\
\text { Mean nuclear crowding }\end{array}$ & $\overline{-}$ & $\bar{n}<0.01$ & $\mathrm{p}<0.01$ & - \\
\hline \multicolumn{5}{|l|}{ Intermediate cell layer } \\
\hline Mean nuclear area & 一 & $\mathrm{p}<0.01$ & $\mathrm{p}<0.01$ & - \\
\hline Mean nuclear contour index & - & - & & - \\
\hline $\begin{array}{l}\text { Mean nuclear polarity } \\
\text { SD nuclear area }\end{array}$ & $\mathrm{p}<0.05$ & $\mathrm{p}<0.01$ & $\mathrm{p}<0.01$ & $p<0.01$ \\
\hline $\begin{array}{l}\text { SD nuclear area } \\
\text { SD nuclear contour index }\end{array}$ & $p=0.07$ & $\mathrm{p}<0.01$ & $\mathrm{p}<0.01$ & - \\
\hline $\begin{array}{l}\text { SD nuclear contour index } \\
\text { SD nuclear polarity }\end{array}$ & - & $\mathrm{p}<0.01$ & - $<001$ & - \\
\hline $\begin{array}{l}\text { Mean nuclear crowding } \\
\text { Muclear polanty }\end{array}$ & $\bar{p}<0.01$ & $\underline{\mathrm{p}}<0.01$ & $\underline{\mathrm{p}}<0.01$ & $\bar{Z}$ \\
\hline \multicolumn{5}{|l|}{ Superficial cell layer } \\
\hline Mean nuclear area & - & - & - & - \\
\hline Mean nuclear contour index & $\mathrm{p}<0.01$ & - & - & - \\
\hline Mean nuclear polarity & - & $\mathrm{p}<0.01$ & $p<0.01$ & $p=0.06$ \\
\hline $\begin{array}{l}\text { SD nuclear area } \\
\text { SD nuclear contour index }\end{array}$ & - & $\underline{p}<0.05$ & - & - \\
\hline $\begin{array}{l}\text { SD nuclear contour index } \\
\text { SD nuclear polarity }\end{array}$ & - & $\bar{p}<0.01$ & $\bar{p}<0.01$ & $\bar{z}$ \\
\hline Mean nuclear crowding & - & - & $\mathrm{p}<0.01$ & $\mathrm{p}<0.01$ \\
\hline
\end{tabular}

*Wilcoxon's two sample test.

$\mathrm{SD}=$ standard deviation.

parameters of the normal epithelium and the three classes (I, II, III) of abnormal epithelium. The results of the statistical analysis carried out to compare the various classes are recorded in Table 3.

There was a significant difference between normal epithelium and class I, class I and class II, and class I and class III for at least five of the parameters used (and even more when the standard deviations were taken into account), but between class II and class III significant differences were found for only three parameters. In Fig. 3 the mean nuclear polarity of

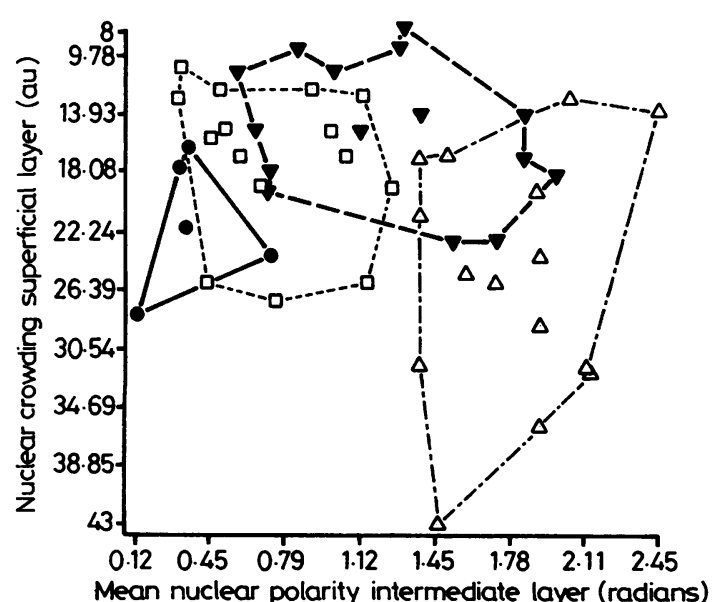

Fig. 3 Scattergram of all cases: normal epithelium $\bullet$, class $I \square$, class II $\nabla$, class III $\triangle$. the intermediate layer has been plotted against the nuclear crowding in the superficial layer of all classes (normal, classes I, II, and III). These two parameters were the most discriminating for class II and class III, according to a stepwise discriminant analysis. ${ }^{14}$ From a graphic representation (Fig. 4) with a function line, which denotes the discriminant function, it appears that within the group of lesions classified as class II one cluster (patients 27, 28, 33, and 35) more or less coincides with class III. Three patients of class III (patients 37, 38, and 50) are above the function line, close to the group of patients of class II. The function line drawn to give an optimal separation of class II and class III has been established by means of a function classification, using the following function: $1.489 \times$ Polar. I. $+0.1047 \times$ NUC.S. $-4.35=0 .{ }^{*}$

A retrospective analysis of the records of patients classified as class II has been carried out to see whether lesions from patients above the line, if not treated other than by endoscopic biopsy, run a different course from those below the line. Seven of 15 patients were excluded from the comparison for the following reasons. Three patients $(26,33$, and 34$)$ at the time had been treated with radiotherapy for their class II lesion. If an infiltrating carcinoma was diagnosed within one year of the first biopsy, as was the case in two patients ( 21 and 23 ), those patients were excluded as well on the assumption that the first biopsy was probably not representative of the *Polar. I. = mean nuclear polarity intermediate layer; NUC. S = mean nuclear crowding superficial layer. 


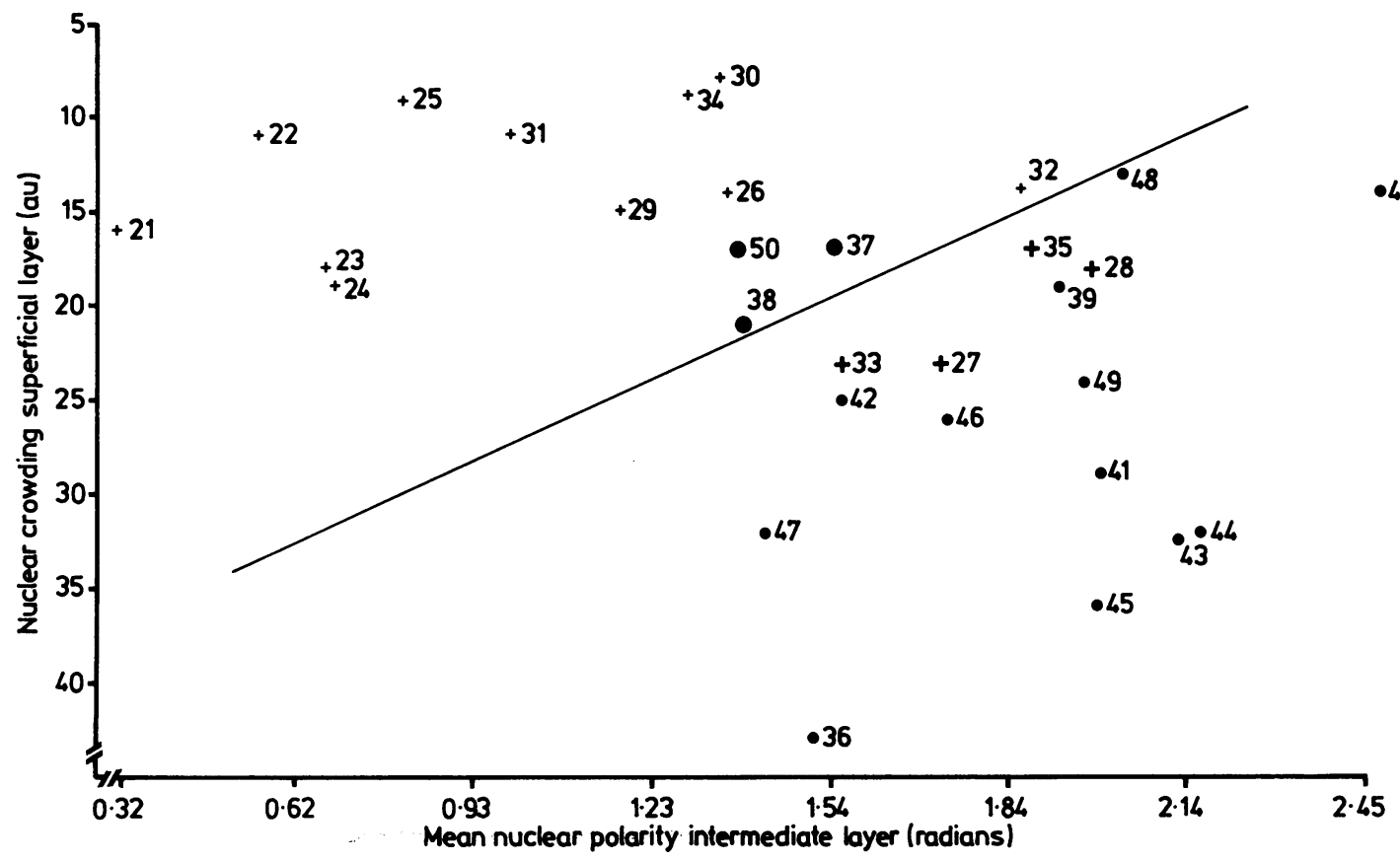

Fig. 4 Scattergram of all cases of class II + class III; + class II (patients 21-35) and - class III (patients 36-50).

lesion. There was also doubt about the first biopsy of one patient (22); within some months after the first biopsy (class II) a second biopsy was done, in which a class III lesion was found. Finally, one patient (29) was excluded because he had been treated with radiotherapy nine years before for an unknown condition of the larynx. Of the remaining five patients of class II above the discriminant function line, one (31) developed a carcinoma after eight years and another (25) showed a carcinoma in situ (class III) within two and a half years. The other three patients of this group followed a favourable clinical course. Of the two patients of the group of class II left below the discriminant function line, one (27) developed a carcinoma after 10 years, whereas another (35) had developed a carcinoma in situ after one year.

All patients of class III have been treated, either with radiotherapy $(n=13)$ or they underwent a cordectomy $(n=2)$. Thus long term follow up on non-treated patients within this group is impossible.

\section{Discussion}

The histological classification of squamous cell lesions is very subjective. ${ }^{5}$ Few studies applying objective methods have been carried out to assess the epithelial characteristics of the so called premalignant lesions of the laryngeal mucosa.
Several workers ${ }^{2-4} 1516$ have performed photometric studies determining nuclear DNA content and nuclear area. Hellquist $e t \mathbf{a l}^{3}$ have investigated, in particular, patients with lesions with dysplasia; the nuclei measured in their study were taken at random through the epithelium. Their findings did not show any morphological or photometric differences between the epithelia with moderate dysplasia which subsequently developed severe dysplasia or carcinoma in situ and those that did not. Apart from doubt regarding its usefulness, it appears unlikely that spectrophotometric analysis will be used routinely if only because it cannot be performed on routine stained material and one also needs expensive photometric equipment.

Quantitative morphometry using simple objective parameters which can be applied on any routine processed material has proved to be of use in grading all kinds of tumours, including bladder ${ }^{17}$ and prostate tumours. ${ }^{18}$ In this study quantitative morphometry was applied to histological slides from patients with squamous cell hyperplasia of the laryngeal epithelium, classified according to Kleinsasser. ${ }^{7}$

Measurements of the nuclei were done in the three layers of the epithelia that can be distinguished: basal, intermediate, and superficial. This appears to be an essential difference from the approach of Hellquist et al. With morphometric 
parameters we showed that between class I and class II and between class I and class III there are six significant parameters. Thus with the assistance of morphometry, especially with the mean nuclear area of the basal and intermediate cell layer (an increase of the nuclear area from class I to class II and from class I to class III in both layers) and with the mean nuclear polarity in all three layers (the polarity expressed in radians increases from class I to class II and from class I to class III in the three layers each) one can easily distinguish between these classes (class I and class II, and class I and class III).

The differentiation between class II and class III, however, is more difficult. Only three significant morphometric parameters between these classes were found. Application of a stepwise discriminant analysis (the features are arranged in a certain sequence to discriminate between the groups; with a combination of two parameters: the mean nuclear polarity of the intermediate layer and the mean nuclear crowding of the superficial layer (Fig. 4)) results in a division into two groups that is not identical to the division by histopathological examination alone: a small cluster of histologically classified class II lesions below the discriminant function line morphometrically falls into the class III category. Unfortunately, we could not determine whether this particular morphometrically identified cluster of class II lesions followed a clinical course typical for class III lesions (for several reasons many patients had to be excluded in the retrospective clinical analysis).

Histological revision of lesions, particularly of class II and class III, even by experienced pathologists is not reproducible in many cases. In this study nuclear areas, shape factors, crowding, and epithelial width have been measured. The morphometric findings are highly reproducible for the classification of squamous cell hyperplasia of the laryngeal mucosa. Furthermore, the findings suggest that the usual histopathological classification of Kleinsasser may be inadequate for there is evidence of two groups within class II above and below the discriminant function line. The clinical course of these two groups needs study and definition.

\section{References}

' Miller AH. Premalignant laryngeal lesions, carcinoma in situ, superficial carcinoma. Can J Otolaryngol 1974;3:573-5.
${ }^{2}$ Gröntoft O, Hellquist H, Olofsson J, Nordström G. The DNA content and nuclear size in normal, dysplastic and carcinomatous laryngeal epithelium. Acta Otolaryngol 1978;86:473-9.

${ }^{3}$ Hellquist H, Olofsson J. Photometric evaluation of laryngeal epithelium exhibiting hyperplasia, keratosis and moderate dysplasia. Acta Otolaryngol 1981;92:157-65.

${ }^{4}$ Hellquist $\mathrm{H}$, Olofsson J, Gröntoft $\mathrm{O}$. Carcinoma in situ and severe dysplasia of the vocal cords. A clinicopathological and photometric investigation. Acta Otolaryngol 1981;92:543-55.

${ }^{5}$ Miller AH, Batsakis JG. Premalignant laryngeal lesions, carcinoma in situ, superficial carcinoma-definition and management. Can J Otolaryngol 1974;3:515.

- Michaels L. Pathology of the larynx. Berlin: Springer Verlag, 1984:185-8.

${ }^{7}$ Kleinsasser O. Uber die verschiedenen Formen der Plattenepithelhyperplasien im Kehlkopf und ihre Beziehungen zum Carcinom. Archiv Ohr- Nas- u Kehlkopf u Zeitschr für Hals- Nasen- und Ohrenh 1959;174:290-313.

${ }^{8}$ Kleinsasser O. Die Klassifikation und Differentialdiagnose der Epithelhyperplasien der Kehlkopfschleimhaut auf Grund histomorphologischer Merkmale. Z Laryng Rhinol 1963; 42:339-62.

' Delemarre JFM. De betekenis van de plaveiselcellige hyperplasie van het larynxepitheel. Doctoral thesis, Free University, Amsterdam, 1970.

${ }^{10}$ Lubsen H. De plaveiselcellige hyperplasie van de larynx en het papilloma inversum van de neus en de neusbijholten. Doctoral Thesis, Free University, Amsterdam, 1980.

" Klein-Szanto AJP, Bánóczy J, Schroeder HE. Metaplastic conversion of the differentiation pattern in oral epithelia affected by leukoplakia simplex. A stereologic study. Path Europ 1976;11:189-210.

12 Meijer CJLM, Van der Loo EM, Van Vloten WA, Van der Velde EA, Scheffer E, Cornelisse CJ. Early diagnosis of mycosis fungoides and Sézary's syndrome by morphometric analysis of lymphoid cells in the skin. Cancer 1980;45:2864 71.

${ }^{13}$ Weibel ER. Stereological principles for morphometry in electron microscopic cytology. Int Rev Cytol 1969;26:235-302.

${ }^{14}$ Statistical package for the Social Sciences, 2nd ed. New York: McGraw-Hill Book Company, 1975.

is Greisen O. Deoxyribonucleic acid content in the laryngeal mucosa with special reference to polyploid cell nuclei. Acta Pathol Microbiol Scand 1975; 83:704-8.

${ }^{16}$ Giarelli L, Silvestri F, Antonutto G, Stanta G. Observations of the pathologist on precancerous lesions of the larynx. Acta Otolaryngol 1977;suppl 344:7-18.

17 Ooms ECM, Essed E, Veldhuizen RW, Alons CL, Kurver P, Boon ME. The prognostic significance of morphometry in $T$, bladder tumours. Histopathology 1981;5:311-8.

${ }^{18}$ Böcking A. Grading des Prostatakarzinoms. Habilitationsschrift, Frieburg, BRD.

Request for reprints to: Dr P Olde Kalter, Department of Otolaryngology and Head and Neck Surgery, Free University Hospital, de Boelelaan 1117, 1081 HV Amsterdam, The Netherlands. 